\title{
SUPPLIER PERFORMANCE MEASUREMENT IN DISCRETE MANUFACTURING INDUSTRY-EMPIRICAL STUDY ON INDIAN MANUFACTURING SECTOR
}

\author{
Manoj Kumar Mohanty ${ }^{1}$, Padmabati Gahan ${ }^{2}$ \\ ${ }^{1}$ Larsen \& Toubro Limited, Kansbahal, Sundargarh, Orissa, India - 770034 \\ ${ }^{2}$ Business Administration Department, Sambalpur University, Burla, Orissa, India - 768019 \\ E-mails: ${ }^{1}$ manojacademics@gmail.com (corresponding author); ${ }^{2}$ p.gahan@rediffmail.com
}

Received 15 August 2011; accepted 10 October 2011

\begin{abstract}
Suppliers are the value creators for the organizations and have emerged as value-adding partners in industrial relationships since last two decades. These values can be derived effectively given the buying organizations keep a long-term strategic relationship with high performing suppliers. To measure the performance organizations have to decide the performance parameters depending on the nature of business and their specific needs from the supply base. The current discrete manufacturing industries of India judging the performance of the suppliers based on technical capability, cost, delivery, quality $\&$ regulatory adherence for safety and environment. But from the larger interest of the manufacturing industry more relevant attributes are needs to be considered, which are explored from our research are responsiveness of the supplier, effectiveness of the aftersales service, delivery flexibility, documentation ability, trust \& commitments. All these performance measurement attributes will drive effectiveness and efficiency of the supply chain.
\end{abstract}

Keywords: supply chain management, supplier performance measurement, Indian manufacturing industry, discrete manufacturing industry, performance factors, performance measurement model.

Reference to this paper should be made as follows: Mohanty, M. K.; Gahan, P. 2013. Supplier performance measurement in discrete manufacturing industry-empirical study on Indian manufacturing sector, Journal of Business Economics and Management 14(2): 330-347.

JEL Classification: M1, M00, C1, C2, L6.

\section{Introduction}

"If you cannot measure it, you cannot manage it" (Garvin 1993). Thus, the ways and means of accurately measuring the performance has been perceived as being an increasingly important field of research for both industry and academics alike. Performance measurement is an essential element of management and also used as a management tool to understand current status of performance and directs to change if required (Amaratunga, Baldry 2002; Tangen 2004). It drives the performance of the elements present in the supply chain, motivates the stake holders, helps in taking decisions, supports better communications, provides feedback and governs behavior. Stainer (1997) believes 
that the performance measure, or a set of performance measures, is used to determine the efficiency and effectiveness of an existing system, or to compare competing alternate systems, by determining the values of the decision variables that yield the most desirable levels of performance. Performance Management (PM) is defined as the use of performance measurement information to effect a positive change in the organizational culture, systems and processes, by helping to set agreed-upon performance goals, allocating and prioritizing resources, informing managers to either confirm or change current policy or program directions to meet these goals, and sharing the results of performance in pursuing these goals (Amaratunga, Baldry 2002).

Current practices of business forced manufacturers for product customization, quality improvement, innovativeness and high responsiveness in order to satisfy the customer demands which are increasing day by day. For sustainability of business, competitiveness and profitability organizations are developing long term partnerships with key suppliers (Shepherd, Gunter 2006; Beamon 1999; Gunasekaran et al. 2004). Key and competent suppliers provide profitability, delivery improvementmproved quality, and innovation. So it is important to have correct and effective suppliers within the supply chain. This means an organization has to select high performing suppliers, regularly judge the performance of the suppliers and to review the performance parameters in regular intervals (Dyer 2000; Dyer, Singh 1998; Gulati et al. 2000). Performance parameter and index may change from time to time depending upon the nature of business and business scenario.

Through this research we have tried to focus on the current practices of the discrete manufacturing industries of eastern parts of India, bridging the gap between existing practices and desired performance measurement attributes through literature review and expert opinions, providing an alternate model for performance measurement and testing the additional factors suggested for including in the performance measurement system through regression analysis.

\section{Literature review in brief}

It has been said that, "the design of supplier performance measurement systems is possibly one of the final structural areas of business in which significant savings can be made". It is becoming an increasingly important strategic tool as trade is getting globalized (Morgan 2004). Performance Measurement Systems (PMS) have been at the top of the research and business agenda over the past few years. According to Neely et al. (1995), performance measurement is defined as the process of quantifying effectiveness and efficiency of action. Effectiveness is the extent to which customers' requirements are met while efficiency measures how economically a firm's resources are utilised.

In the current business practice supply chain compete with each other not the firms. So it is more important to measure the performance of the supply chain, more precisely to judge the performance of the supply chain partners. One of the major contributors to the supply chain performance is supplier. Supply chain management has become common practice across industries since it addresses long-term strategic alliance, supplier- 
buyer partnerships, cross-organizational logistics management, joint planning, control of inventory, and information sharing (Banomyong, Supatn 2011). Current supply chain practices focusing on long term partnership, with few suppliers to derive the cost, quality, delivery and related benefits. Partnerships have the potential benefit of eliminating redundant pool of inventory and duplicate service operations while reducing costs (Chan et al. 2006).

In a survey of 350 Fortune-500 companies Krause and Ellram (1997) found that performance evaluation is deemed a vital part of supplier development programs. Carr and Pearson (1999) conducted a study of 739 firms in a cross industry analysis and observed that firms with a strategic approach to purchasing are more involved in supplier evaluation than other firms. It is shown also that this strategic approach is having a positive impact on buyer seller relationships and, finally, supplier evaluation systems is having a positive effect on the buying firm's financial performance.

Supplier selection is a multi-criteria decision making problem which includes selection and evaluation factors. In order to select the best suppliers it is crucial to considering the both qualitative and quantitative factors. Cost, quality and delivery used to be the dominating dimension in the evaluation of supplier performance since long time. Over the time a number of complementary dimensions have been proposed, but in practice the majority of supplier evaluations for long tended to be routinely viewed as consisting of just three factors: price/cost, quality, and delivery (Hirakubo, Kublin 1998). Multiple criteria models used by many researchers like Talluri, Sarkis (2002), Weber (1996), Roodhooft and Konings (1996), Tan, Lyman and Wisner (2002), Petersen et al. (2005), Mentzer (2001), Keegan et al. (1989), Sink, Tuttle (1989) for supplier performance measurement with following dimensions and aspects:

- Product and delivery assessment, including evaluations of quality level, on-time delivery, correct quantity, service level and price/cost of product.

- Capacity assessment, including evaluations of willingness to change product/services to meet changing needs flexible capacity and communication skills/systems.

- Information assessment, including evaluations of willingness to share sensitive information and to participate in new product development and value analyses.

Dickson (1996) in their study considered quality, delivery and performance history areas the most important criteria in supplier selection while other important criteria defined by Dickson include warranties and claim policies, production facilities and capacity and price. A comprehensive review of 74 articles by Weber (1996) indicated that price (discussed in $80 \%$ of the articles) is the most important criteria, followed by delivery $(59 \%)$ and quality (54\%). Other criteria like production facilities and capability, geographical location, and technical capability were discussed in $31 \%, 22 \%$ and $20 \%$ of the articles respectively while warranties and claim policies are not discussed in any of the 74 articles.

For manufacturer like casting, supplier assessment should be based on four groups of criteria i.e. product development capability, manufacturing capability, quality capability, and cost and delivery in their proposed AHP model (Akarte et al. 2001). In project management the best contractor's performance judged based on six criteria: 
experience, financial stability, quality performance, manpower resources, equipment resources, and current workload (Al-Harbi 2001). The criteria used to rate suppliers are quality, delivery, price, technical capability, financial position, past performance attitude, facilities, flexibility and service (Muralidharan et al. 2002). Research carried out by (Mohr, Spekman 1994; Masella, Rangone 2000; Perçin 2006; Ghodsypour, O’Brien 1998; Akarte et al. 2001; Al-Harbi 2001; Muralidharan et al. 2001) using AHP model for performance measurement states the attributes of performance measurement should be coordination, commitment, trust, information sharing, and conflict management. Coordination involves the tasks that are to be taken for linking activities performed by the different members in a seamless manner. Commitment refers to the willingness of the supplier to perform effort on behalf of the relationship. It is the establishment of the foundation of the relationship and it is based on being supportive in solving problems together. A high level of commitment provides the context for the achievement of individual and mutual goals. Trust is based on the belief that the partner is reliable and will fulfill its responsibilities acting fairly. A partner trusts another partner if considers that decisions made by this last one will be in the interest of both parts. Information sharing considers the timeliness, accuracy, adequacy and completeness of the relevant information exchanged.

Integrated decision analysis model suggested by Hwang (2004) used the following as supplier performance measurement criteria. (1) Meeting the lead time, (2) Inventory rotation rate, (3) Lead time, (4) Customer satisfaction, (5) Market share, (6) Production flexibility, (7) Multi-item production capability, (8) New item development/production capability, (9) Quality assurance, (10) Return penalty, and (11) after service level. Balance score card method suggest by (Kaplan, Norton 1992; Brewer, Speh 2000; Bititci et al. 2005; Folan, Browne 2005; Alfaro et al. 2007) for supplier performance measurement taking above criteria.

Where customized product is desired means design-to-order products, and where additional services and value-added benefits like product upgrades and future reconfigurations are as important as the product itself there technology capability of the suppliers needs to be assessed like capability of rapid prototyping (RP), rapid tooling (RT), and reverse engineering (Kahraman, Kaya 2010). Apart from this they have suggested quality, delivery, agility, performance, supplier management, service ability for supplier development. Researcher Jongkyung et al. (2010) described the important criteria of each evaluation process are as follows: (1) Capabilities, including quality systems, technological capability, financial capability, reputation, geographic location, organization, production capacity, and open communication. (2) Performance, including quality, cost, and delivery. (3) The collaborative relationship which includes, mutuality, cooperation, commitment, trust, conflict resolution and compliance.

Commitment encourages channel members to resist short-term benefits in favor of the anticipated long-term benefits associated with a continuation of the relationship between existing partners (Morgan, Hunt 1994). Thus, a highly committed manufacturer should pursue a cooperative relationship with its supplier, including the cooperative pursuit of cost-effectiveness (Green 2000). Manufacturers with a low levels of commitment, 
therefore, focus on maximizing their current profits in a given transaction, whereas manufacturers with a high level of commitment rely on relational exchanges to maximize their long-run profits (Ganesan 1994). In the study of the electronics industry it is so observed that purchasing, engineering, and production/operations are the functions mostly involved in evaluation. Also R\&D, general management, and finance played some role in this respect. Safety and environment regulation adherence also becomes a mandatory requirement for supplier performance evaluation (Samuel, Keskar 2007; Humphreys et al. 2003).

\section{Discrete manufacturing industry and expectations from suppliers}

Manufacturing industry may be categorized mainly into three parts i.e. continuous manufacturing, repetitive manufacturing and discrete manufacturing. Out of which discrete manufacturing demands a lot of attention towards engineering, product knowledge, process knowledge, technology and materials management. In discrete manufacturing, the manufacturing is based on specific orders with specific technical requirements from the customer or consultants. A typical discrete manufacturing process is composed of multiple sub-processes which call for different set of process or skill. It is often characterized by individual or unit production style. Usually low volume and high complexity is observed in discrete manufacturing sectors. Our research area, the organizations of eastern parts of India is also witnessing the above mentioned characteristics. Each function or sub process of manufacturing is different from each other. Function remaining same the skill and technical requirements observed different from one order to another. The manufacturing units' customers are from coal, cement, wind power, steel, power and paper industry. The technical parameter differs within the segments with the same machine capacity so as the manufacturing process also. But having so many variations the organizations have to meet the schedule target with a defined cost line. Current business practices and competition forced the discrete manufacturing industry to become effective in process control, manufacturing flexibility and cost control along with continuous increase in productivity. Accordingly the supply base and supply network to be effective, efficient and responsive.

As the success of the manufacturing industry largely depends upon the performance of the supply base, it is very essential to identify the desired performance measurement attributes which suits to the desired needs of individual organization. Keeping the objective in view we have taken the expert opinion of 16 buyer heads that are having more than 22 years of experience in manufacturing outsourcing and material management. Through structured interviewed their expectations from the suppliers are summarized. These are (1) Organization should get a substantial cost benefit out of supplier partnership, (2) Quality of the products should be as good as the quality of original manufacturer (OEM) or meeting the end customer requirement, (3) Delivery must be in line or before the schedule demand, (4) Supplier must understand the technical parameters mentioned in the customer drawings or drawings and bill of material issued for manufacturing, (5) In case of any doubt supplier must consult the buyer 
rather than taking a decision with his/her expertise, (6) Supplier should follow all the latest manufacturing practices, (7) Supplier should be capable of any special material desired during manufacturing of a specific sub assembly or equipment, (8) All required tools and technology must be equipped with the supplier, (9) Supplier should not violate any types of governmental rules and regulations during executing the order, (10) Supplier must intimate the deviations occurred during execution of jobs ordered by OEM, (11) Good labor practice must be as a part of supplier qualification rather than desired attribute, (12) Responsive suppliers preferred in any organization, (13) Timely documentations, clarification to incorrect documents released to supplier is desired, (14) Supplier should not discuss anything regarding the job, drawing, bill of material (BOM) with any other supplier or the buyer outside organization, (15) Total confidentiality must be a part of partnership.

\section{Bridging the gap between current practices and desired performance measurement attributes of discrete manufacturing industry}

The literature suggests two types of performance measurement variables at gross level, i.e. quantitative and qualitative variables. Most of the previous researchers' performance parameters are falling under these two categories. The variables observed under quantitative category are cost, quality, delivery, technical competency, financial capability, manufacturing flexibility, new product development capability, aftersales service, safety and environmental regulation adherence and market share. Variables observed under qualitative category are mutuality, responsiveness, trust, commitment, loyalty, information sharing, conflict resolution and reputation.

Discrete manufacturing industries under study are measuring performances through technical competency, cost, quality, delivery compliance, financial capability, statutory compliance of safety and environmental protection. Literature review and expert opinion suggests that for manufacturing industries other performance parameters also to be considered that are responsiveness, effectiveness in aftersales service, logistic ability, delivery flexibility, documentation ability, trust and commitment. These additional factors must be included in the performance measurement criteria when we are defining performance system for suppliers.

The above additional criteria apart from the existing performance parameters are having justifications in performance measurement system of manufacturing industries. The demand for product or service in manufacturing industry varies from time to time. In times there may be quality problem, there may be low or high demand for particular component. In such cases one responsive supplier is needed to cater to the changing demands. Life of the buyers can only be easy when there is a pool of responsive suppliers. Aftersales service is the factor creates satisfaction or dis-satisfaction among customers. The better the aftersales service the higher the reputation and this also leads to the customer retention. As some items are directly delivered to the customer from supplier's end, it is mandatory to judge the performance in the aftersales service ability of supplier. Ultimately the OEM is responsible for the supplier's product too. Logistic 
ability is an art through which cost saving, time saving and manufacturing flexibility can be achieved. It can directly save the cost of transportation, delivery schedule adherence and can make smooth production system. Delivery flexibility means supply of products or components based on the actual requirement of the OEM at a particular time frame irrespective of quantity. Delivery flexibility helps in making agile supply chain. It helps in controlling the inventory cost and effective storing place management. Proper documentation ability helps in keeping clarity in all the levels of management particularly from audit perspective, store data management, payment process in accounts. It also avoids conflict between buyers and suppliers at a later stage of business. Trust and commitment parameter applied to all sector of outsourcing business. In manufacturing organisations key element like engineering drawings, material specifications, collaborators drawings, specific grade material, special tools and tackles passes through the suppliers. This may lead to exposure of technical competencies and manufacturing secrets to other competitors followed by loss of business. So trust and commitment becomes very important to this segment of business. Though many organisations make confidentiality agreement with suppliers, but this does not help much. Only a trusted and committed supplier should be selected for long term partnership.

\section{Proposed performance measurement model}

"When you can measure what you are speaking about, and express it in numbers, you know something about it...[otherwise] your knowledge is of a meager and unsatisfactory kind; it may be the beginning of knowledge, but you have scarcely in thought advanced to the stage of science" (Lord Kelvin, 1824-1907).

Suppliers are to be of major strategic importance to most companies today as substantial amount of the resources used by a company are made available through its suppliers. That's why the performance of the organisation largely depends upon the performances of its suppliers. The performance will be only effective if proper evaluation criteria and process followed in organisations.

Before starting the performance measurement process organisation has to take care some of the key aspects of measurement from the organisational interest. They are:

- Supplier performance measurement must be aligned with the organisational strategies of the evaluating organisation.

- Collect sufficient information about the supplier.

- Dedicated team must be formed under the leadership of buyer head.

- Organisation must avoid persons having biasness towards particular supplier including in the evaluation team.

- As far as possible help of system must be taken, so that correct and accurate information can be availed during performance measurement process.

- Supplier evaluation must be considered as a continuous process and preferably within the timeframe decided by the organisation. 


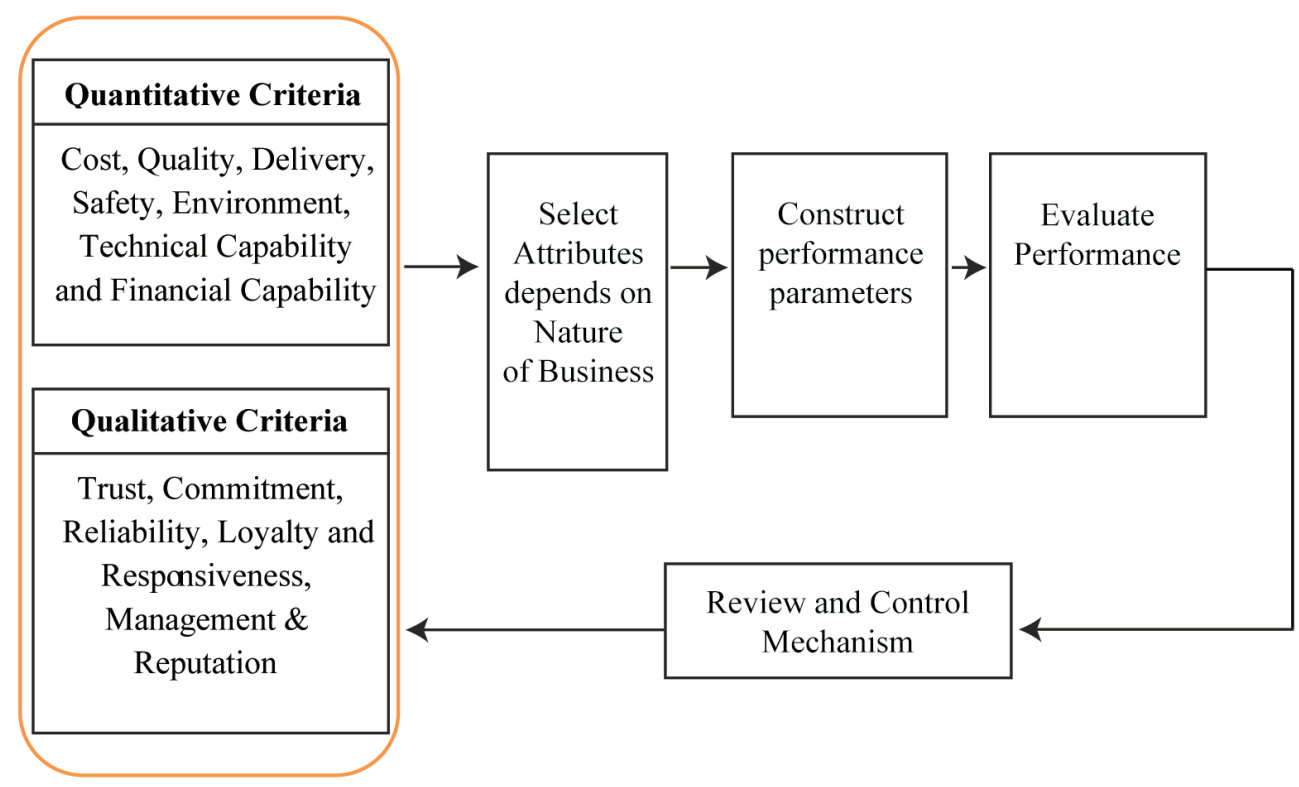

Fig. 1. Proposed Supplier performance model

Source: Authors 2011.

\section{Process of measurement}

- Evaluation team must understand the organizational strategic parameters and they must link those parameters to the performance parameters for suppliers. If the objective of organizational and the supplier will not be in a single direction then the evaluation process has no meaning.

- Depending upon the organizational strategy quantitative and qualitative attributes must be selected as mentioned in the model. Depending upon the nature of business these attributes may change.

- Measuring parameters must be constructed with due consultation with experts and cross functional team members. Proper weightage must be assigned before proceeding further. In this course of action Delphi technique may be help in finding and assigning the appropriate weightage to selected attributes. Proper format or system must be generated in this period to evaluate each supplier. The retention and de-listing criteria must be decided in this phase, depending upon the overall score.

- Each supplier must be evaluated as per the measurement system developed by the organization. During the measurement process respective buyers should evaluate the suppliers with whom they are dealing with. Other evaluators must not participate in that event.

- Depending upon the overall assessment score list of retention and list of de-listed supplier must be prepared along with the consent of the team members.

- The result of the evaluation must be communicated to individual supplier. The need of training in specific area for specific supplier and any special initiative must be 
M. K. Mohanty, P. Gahan. Supplier performance measurement in discrete manufacturing industry-empirical ...

discussed in the team and course of action to be documented and implemented.

- During this process and the outcome of the result some modification may be required to the evaluation attributes or the process itself. These changes should be adopted depending upon organizational requirements. The system must be reviewed continuously for further improvement.

- Feedback from the suppliers also needs to be taken about the criteria and the process itself. They may suggest some bright ideas which will helpful to both organization and the suppliers too. This will become an all- party agreement for a common goal and indicates clarity, transparency and healthy relationship.

\section{Hypotheses formulation}

The following null hypotheses are formulated based on prevailing practices of the research area, literature review and expert opinions.

$\mathbf{H}_{\mathbf{0 1}}$ : Responsiveness of supplier is not directly linked to the supplier performance

$\mathbf{H}_{\mathbf{0 2}}$ : Technical competency is not the prime factor in performance measurement

$\mathbf{H}_{\mathbf{0 3}}$ : Effectiveness in aftersales service does not impact supplier performance measurement

$\mathbf{H}_{\mathbf{0 4}}$ : Trust and commitment is not an essential component for supplier performance measurement.

\section{Research methodology}

This research work is carried out in the discrete manufacturing industries India. To avoid the biasness we have taken survey of six similar natures of industries. Sample is selected based on experience and exposure to the subject knowledge. It covers the decision/policy makers of the supplier chain management, sectional buyers and the cross functional team members those who are involved in the purchasing process and having reasonable amount exposure (15 + years of experience) to the purchasing environment. Data collected through sample size of 100 through structured questionnaire. A usable sample of 82 is considered for analysis, rest 18 are rejected for incomplete information. The structured questionnaire is developed based on the extensive literature review and working experiences of the authors. The questionnaire is designed using five point Liker scales where 1 meant strong disagreement and 5 meant strong agreement with a particular selection criterion of the supplier. The scale reliability is found to be 0.715 which is above the accepted level (Nunally 1978). The Statistical Package for Social Sciences (SPSS version 18.0) was used to run the data.

\section{Data analysis}

Data collected through selected samples using questionnaire method. To measure and reassure the internal consistency, reliability test is conducted on the 13 variables ( 1 dependent 
and 12 independent) using 13 questions. Table 1 exhibits the scale reliability data. The scale reliability (Cranach's alpha) is found to be 0.715 which is found to be above the accepted level (Nunally 1978). Ideally value of Cranach's alpha above 0.50 will be accepted if the number of questions is small. The results inferred the questionnaire is for measuring the supplier performance criteria in manufacturing industry in a meaningful way.

Table 1. Data Reliability Test (Cronbach's Alpha)

\begin{tabular}{c|c|c|c|c|c|c}
\hline \multicolumn{5}{c|}{ Case Processing Summary } & & \multicolumn{2}{c}{ Reliability Statistics } \\
\hline & & $\mathrm{N}$ & $\%$ & & Cronbach's Alpha & N of Items \\
\hline Cases & Valid & 82 & 100 & & 0.715 & 13 \\
\hline & Excluded & 0 & 0 & & & \\
\hline & Total & 82 & 100 & & & \\
\hline
\end{tabular}

a. List wise deletion based on all variables in the procedure.

\section{Descriptive statistics}

Descriptive statistics are used in table 2 to illustrate the main features of a dataset in quantitative terms. It aims to quantitatively summarize a data set, rather than being used to support inferential statements. All variables contain a sample size of 82 which verified consistency in capturing the data. The statistical mean value for all the variables falls between 2.76 and 4.21. The greatest standard deviation is 1.15 found on ethical practice as performance indicator. The minimum standard deviation observed is 0.55 on technical capability as supplier performance indicator in the dependent variable category.

Table 2. Descriptive Statistics

\begin{tabular}{c|c|c|c|c|c|c|c}
\hline & $\mathrm{N}$ & Mean & $\begin{array}{c}\text { Std. } \\
\text { Deviation }\end{array}$ & \multicolumn{2}{|c|}{ Skewness } & \multicolumn{2}{c}{ Kurtosis } \\
\hline & Statistic & Statistic & Statistic & Statistic & Std. Error & Statistic & $\begin{array}{c}\text { Std. } \\
\text { Error }\end{array}$ \\
\hline VAR00001 & 82 & 4.1585 & .55488 & .060 & .266 & .065 & .526 \\
\hline VAR00002 & 82 & 2.9878 & .76164 & .021 & .266 & -1.258 & .526 \\
\hline VAR00003 & 82 & 3.1829 & .90442 & -.374 & .266 & -1.692 & .526 \\
\hline VAR00004 & 82 & 3.2561 & .82867 & -.514 & .266 & -1.354 & .526 \\
\hline VAR00005 & 82 & 2.7683 & .79036 & .441 & .266 & -1.261 & .526 \\
\hline VAR00006 & 82 & 3.2073 & .82758 & -.407 & .266 & -1.423 & .526 \\
\hline VAR00007 & 82 & 4.0976 & .93769 & -1.119 & .266 & .607 & .526 \\
\hline VAR00008 & 82 & 3.0122 & 1.03630 & .453 & .266 & -1.166 & .526 \\
\hline VAR00009 & 82 & 3.1463 & .70487 & -.214 & .266 & -.946 & .526 \\
\hline VAR00010 & 82 & 3.0488 & 1.15366 & .447 & .266 & -.864 & .526 \\
\hline VAR00011 & 82 & 3.3171 & .82967 & -.657 & .266 & -1.230 & .526 \\
\hline VAR00012 & 82 & 2.8659 & .89941 & 1.001 & .266 & .437 & .526 \\
\hline VAR00013 & 82 & 4.2195 & .47204 & .631 & .266 & .095 & .526 \\
\hline Valid N (list wise) & 82 & & & & & & \\
\hline & & & & & & &
\end{tabular}


M. K. Mohanty, P. Gahan. Supplier performance measurement in discrete manufacturing industry-empirical ...

Kurtosis and skewness statistics and calculations demonstrate that the distribution is normal because kurtosis and skewness are much in between -2 and +2 , thus data is quite normally distributed and is having reasonable variance to use in subsequent analysis (Mardia 1974).

\section{Regression analysis}

To understanding of the relationship between the supplier performance and the identified dimensions, regression analysis is used. The independent variable and the dependent variable used in the regression analysis are as follows.

13 questionnaires used for data collection. 12 questions used as independent variables and 1 question used for dependent variable, which is explained below:

- Independent variables $(X)$ : The proposed twelve dimensions are treated as independent variables for the regression equation. These are: 'Technical Capability' $\left(X_{1}\right)$, 'Quality' $\left(X_{2}\right)$, 'Logistic ability' $\left(X_{3}\right)$, 'cost' $\left(X_{4}\right)$, 'Delivery reliability' $\left(X_{5}\right)$, Effectiveness of aftersales service $\left(X_{6}\right)$, 'Documentation Ability' $\left(X_{7}\right)$, 'Delivery Flexibility' $\left(X_{8}\right)$, Responsiveness $\left(X_{9}\right)$, Ethical Practice $\left(X_{10}\right)$, Regulatory Adherence $\left(X_{11}\right)$ and 'Trust and commitment' $\left(X_{12}\right)$.

- Dependent Variable $(Y)$ : The retention of the supplier based on performance is treated as dependent variable.

The mathematical representation of the regression equation can be written as follows:

$Y=b 0+b 1 X 1+b 2 X 2+b 3 X 3+b 4 X 4+b 5 X 5+b 6 X 6+b 7 X 7+b 8 X 8+$

$b 9 \times 9+b 10 \times 10+b 11 \times 11+b 12 \times 12$,

where value of dependent variable $b 0=$ constant when values of independent variables are zero $=$ also called intercepts, because it determines where the regression line meets the $Y$-axis. $b 1 \ldots b 12=$ coefficients that represent the estimated change in mean value of dependent variable for each unit change in the independent variable values.

Now, considering the values from the Table 3 , the regression equation will be in the following form:

$Y=-0.926+0.707 X 1+0.146 X 2-0.038 X 3-0.12 X 4+0.026 X 5+0.16 X 6-$ $0.01 X 7-0.04 X 8+0.217 X 9+0.024 X 10+0.046 \times 11+0.158 X 12$.

It is observed from Table 3 that the relationship between the supplier performance (Retention) $(Y)$ and the various dimensions $\left(X_{1} \ldots X_{12}\right)$ are more or less statistically significant at $95 \%$ confidence level $(p<0.05)$ except variable $3,4,7$ and 8 . The values of these variables are also very small in quantitative terms. Also, the adjusted $R 2$ value is 0.82 , which indicates thatthe relationship is statistically significant. Five dimensions such as 'Technical capability' $\left(X_{1}\right)$, Quality $\left(\mathrm{X}_{2}\right)$, Effectiveness in aftersales Service $\left(X_{6}\right)$, 'Responsiveness' $\left(X_{9}\right)$, 'Trust and commitment ' $\left(X_{12}\right)$, are statistically significant $(p<0.05)$. The summary of the regression model is mentioned in the table 4 . 
Table 3. Relationship between supplier retention with dependent variables

\begin{tabular}{|c|c|c|c|c|c|c|}
\hline \multicolumn{7}{|c|}{ Coefficients } \\
\hline & \multirow[b]{2}{*}{ Model } & \multicolumn{2}{|c|}{$\begin{array}{l}\text { Un-standardized } \\
\text { Coefficients }\end{array}$} & \multirow{3}{*}{$\begin{array}{c}\text { Standardized } \\
\text { Coefficients } \\
\text { Beta } \\
\end{array}$} & \multirow{3}{*}{$\frac{\mathrm{t}}{-1.518}$} & \multirow{3}{*}{$\frac{\text { Sig. }}{.134}$} \\
\hline & & $\mathrm{B}$ & Std. Error & & & \\
\hline \multirow[t]{13}{*}{1} & (Constant) & -.926 & .610 & & & \\
\hline & VAR00001 & .707 & .139 & .831 & 5.093 & .000 \\
\hline & VAR00002 & .146 & .087 & .235 & 1.671 & .009 \\
\hline & VAR00003 & -.038 & .066 & -.073 & -.579 & .564 \\
\hline & VAR00004 & -.012 & .060 & -.022 & -.206 & .837 \\
\hline & VAR00005 & .026 & .073 & .044 & .362 & .718 \\
\hline & VAR00006 & .160 & .058 & .281 & 2.748 & .008 \\
\hline & VAR00007 & -.001 & .027 & -.003 & -.049 & .961 \\
\hline & VAR00008 & -.004 & .057 & -.008 & -.063 & .950 \\
\hline & VAR00009 & .217 & .079 & .325 & 2.757 & .007 \\
\hline & VAR00010 & .024 & .021 & .058 & 1.107 & .272 \\
\hline & VAR00011 & .046 & .081 & .082 & .577 & .566 \\
\hline & VAR00012 & .158 & .049 & .301 & 3.244 & .002 \\
\hline \multicolumn{4}{|c|}{ a. Dependent Variable: VAR00013 } & & & \\
\hline
\end{tabular}

Table 4. Model Summary

\begin{tabular}{c|c|c|c|c}
\hline \multicolumn{5}{c}{ Model Summary } \\
\hline \multirow{2}{*}{ Model } & $\mathrm{R}$ & R Square & Adjusted R Square & $\begin{array}{c}\text { Std. Error of the } \\
\text { Estimate }\end{array}$ \\
\hline 1 & $.923^{\mathrm{a}}$ & .853 & .827 & .19636 \\
\hline
\end{tabular}

a. Predictors: (Constant), VAR00012, VAR00007, VAR00002, VAR00010, VAR00004, VAR00008, VAR00006, VAR00009, VAR00005, VAR00011, VAR00003, VAR00001

Note: $R 2=85.30 \% ; R 2$ (adj.) $=82.70 \%$ statistically significant.

\section{Testing of hypotheses}

The adjusted $\mathrm{R}$ Square value $82 \%$ indicates that the data is statistically significant. The ranking of the attributes impacting supplier performance measurement exhibited in the table 5 .

\section{Hypotheses $1\left(\mathrm{H}_{01}\right)$}

The significance value of Responsiveness of suppliers found to be 0.007 , which is less than 0.05 and indicates high significance. Also from the beta value ranking responsiveness found to be in $2^{\text {nd }}$ position out of all variables considered for supplier performance. So it can be said that the responsiveness of suppliers is directly linked to the supplier performance. Hence hypothesis 1 stands rejected. 
M. K. Mohanty, P. Gahan. Supplier performance measurement in discrete manufacturing industry-empirical ...

Table 5. Ranking of Supplier Performance Attributes

\begin{tabular}{c|l|c|c}
\hline \multicolumn{1}{c|}{ VAR } & \multicolumn{1}{|c|}{ DESCRIPTION } & "B” VALUE & Rank \\
\hline VAR00001 & Technical Capability & 0.714 & 1 \\
\hline VAR00009 & Responsiveness & 0.205 & 2 \\
\hline VAR00012 & Trust and commitment & 0.158 & 3 \\
\hline VAR00006 & Effectiveness of After sales service & 0.153 & 4 \\
\hline VAR00002 & Quality & 0.139 & 5 \\
\hline VAR00011 & Regulatory Adherence & 0.05 & 6 \\
\hline VAR00005 & Delivery reliability & 0.029 & 7 \\
\hline VAR00010 & Ethical Practice & 0.021 & 8 \\
\hline VAR00008 & Delivery flexibility & 0 & 9 \\
\hline VAR00007 & Documentation Ability & -0.014 & 10 \\
\hline VAR00004 & Cost & -0.022 & 11 \\
\hline VAR00003 & Logistic ability & -0.035 & 12 \\
\hline
\end{tabular}

\section{Hypotheses $2\left(\mathrm{H}_{02}\right)$}

The significance value towards the technical competency of the supplier with respect to performance measurement is found to be 0.000 and it indicates a very high significance role in deciding supplier performance. From the beta value ranking the technical competency is also ranked as one. Hence it can conclude that technical competency is considered as prime factor in supplier performance. Hence hypothesis 2 stands rejected.

\section{Hypotheses $3\left(\mathbf{H}_{03}\right)$}

The significance value towards the effectiveness in the aftersales service of the supplier with respect to performance measurement is found to be 0.008 and it indicates playing significant role in supplier performance measurement. The beta value ranking positions the aftersales service factor as four. Hence it can conclude that effectiveness in aftersales service is considered as one of the important factor in supplier performance. Hence hypothesis 3 stands rejected.

\section{Hypotheses $4\left(\mathrm{H}_{04}\right)$}

The significance value towards the trust and commitment of the suppliers with respect to performance measurement is found to be 0.002 which indicates high significance in performance measurement. The beta value ranking indicates its position as three. Hence it can conclude that trust and commitment is considered as essential element in supplier performance. Hence hypothesis 4 stands rejected.

\section{Conclusion}

Supplier performance measurement attributes differs from business to business. It all depends which attributes are critical or important for the specific business. As per the 
requirement of the organization the performance indicators and levels are decided. It is observed that the manufacturing industries of the research areas are having supplier performance indicators as technical capability, cost, delivery, quality \& regulatory adherence for safety and environment. But from the manufacturing industry perspective more attributes are needs to be considered, which are explored from the above data analysis carried out from the buyers and feedbacks from supply chain experts from the industry. Those are responsiveness of the supplier, effectiveness of the aftersales services, delivery flexibility, documentation ability and trust and commitments. This research indicates manufacturing set-ups have to include other performance parameters like effectiveness in aftersales service, responsiveness of the supplier and trust and commitment of suppliers. If all these parameters are tested on suppliers and based on this supplier listing will be done, it would meet the organizational requirement and ultimately supply chain effectiveness.

\section{References}

Akarte, M. M.; Surendra, N. V.; Ravi, B.; Rangaraj, N. 2001. Web based casting supplier evaluation using analytical hierarchy process, Journal of the Operational Research Society 52: 511-522. http://dx.doi.org/10.1057/palgrave.jors.2601124

Alfaro, J. J.; Ortiz, A.; Rodríguez, R. 2007. Performance measurement system for Enterprise Networks, International Journal of Productivity and Performance Management 56(4): 305-334. http://dx.doi.org/10.1108/17410400710745324

Al-Harbi, K. M. 2001. Application of AHP in project management, International Journal of Project Management 19(4): 19-27.

Amaratunga, D.; Baldry, D. 2002. Moving from performance measurement to performance management, Facilities 20(5-6): 217-223.

Banomyong, R.; Supatn, N. 2011. Developing a supply chain performance tool for SMEs in Thailand, supply chain management, International Journal 16(1): 20-31.

Beamon, B. M. 1999. Measuring supply chain performance, International Journal of Operations \& Production Management 19(3): 275-288. http://dx.doi.org/10.1108/01443579910249714

Bititci, U. S.; Mendibil, K.; Martinez, V.; Albores, P. 2005. Measuring and managing performance in extended enterprises, International Journal of Operations and Production Management 25(4): 333-353. http://dx.doi.org/10.1108/01443570510585534

Brewer, P. C.; Speh, T. W. 2000. Using the balanced Score Card to measure supply chain performance, Journal of Business Logistics 21(1): 75-93.

Carr, A. S.; Pearson, J. N. 1999. Strategically managed buyer-supplier relationships and performance outcomes, Journal of Operations Management 17: 497-519.

http://dx.doi.org/10.1016/S0272-6963(99)00007-8

Chan, F.; Chan, H.; Lau, H.; Ip, R. 2006. An AHP approach in benchmarking logistics performance of the postal industry, Bench-marking: An International Journal 13(6): 636-661.

Dickson, G.1996. An analysis of vendor selection systems and decisions, Journal of Purchasing (2): $28-41$.

Dyer, J. H. 2000. Collaborative Advantage. Winning through Extended Enterprise Supplier Networks. Oxford: Oxford University Press.

Dyer, J. H.; Singh, H. 1998. The relational view: cooperative strategy and sources of inter organizational competitive advantage, Academy of Management Review 23(4): 660-679. 
M. K. Mohanty, P. Gahan. Supplier performance measurement in discrete manufacturing industry-empirical ...

Ellram, L. 1990. The supplier selection decision in strategic partnerships, Journal of Purchasing and Materials Management 26(4): 8-14.

Folan, P.; Browne, J. 2005. Development of an extended enterprise performance measurement system, Production Planning and Control 16(6): 531-544.

http://dx.doi.org/10.1080/09537280500112355

Ganesan, S. 1994. Determinants of long-term orientation in buyer-seller relationships, Journal of Marketing 58(2): 1-19. http://dx.doi.org/10.2307/1252265

Garvin, D. A. 1993. Building a learning organization, Harvard Business Review 71(4): 78-91.

Ghodsypour, S. H.; O’Brien, C. 1998. A decision support system for supplier selection using an integrated analytic hierarchy process and linear programming, International Journal of Production Economics 56-57, 199-212. http://dx.doi.org/10.1016/S0925-5273(97)00009-1

Green, J. 2000. Tight squeeze at Chrysler, Business Week October(9): 54.

Gulati, R.; Nohria, N.; Zaheer, A. 2000. Strategic networks, Strategic Management Journal 21(3): 203-215. http://dx.doi.org/10.1002/(SICI)1097-0266(200003)21:3<203::AID-SMJ102>3.0.CO;2-K

Gunasekaran, A.; Patel, C.; Mc Gaughey, R. E. 2004. A framework for supply chain performance measurement, International Journal of Production Economics 87: 333-347.

http://dx.doi.org/10.1016/j.ijpe.2003.08.003

Hirakubo, N.; Kublin, M. 1998. The relative importance of supplier selection criteria: the case of electronic components procurement in Japan, International Journal of Purchasing and Materials Management Spring: 19-24.

Humphreys, P. K.; Wong, Y. K.; Chan, F. T. S. 2003. Integrating environmental criteria into the supplier selection process, Journal of Materials Processing Technology 138: 349-356.

http://dx.doi.org/10.1016/S0924-0136(03)00097-9

Hwang, H. S. 2004. Web-based multi-attribute analysis model for engineering project evaluation, International Journal of Computers and Industrial Engineering 46(1): 669-678.

Jongkyung, P.; Shin, K.; Chang, T. W.; Park, J. 2010. An integrative framework for supplier relationship management, Industrial Management and Data Systems 110(4): 495-515.

http://dx.doi.org/10.1108/02635571011038990

Kahraman, C.; Kaya, I. 2010. A fuzzy multi criteria methodology for selection among energy alternatives, Expert Systems with Applications: An International Journal 37(9): 6270-6281.

Kaplan, R. S.; Norton, D. P. 1992. The balanced scorecard - measures that drive performance, Harvard Business Review 70(1): 71-79.

Keegan, D.; Eiler, R.; Jones, C. 1989. Are your performance measures obsolete, Management Accounting 70(12): 45-50.

Krause, D. R.; Ellram, L. M. 1997. Critical elements of supplier development, European Journal of Purchasing and Supply Management 3(1): 21-31.

http://dx.doi.org/10.1016/S0969-7012(96)00003-2

Mardia, K. V. 1974. Applications of some measures of multivariate skewness and kurtosis in testing normality and robustness studies, Sankhya, The Indian Journal of Statistics 36 (Series B): 115-128.

Masella, C.; Rangone, A. 2000. A contingent approach to the design of vendor selection systems for different types of co-operative customer/supplier relationships, International Journal of Operations and Production Management 20(1): 70-84. http://dx.doi.org/10.1108/01443570010287044

Mentzer, J. 2001. Managing Supply Chain Collaboration. Supply Chain Management. Sage Publications, Inc., Thousand Oaks.

Mohr, J.; Spekman, R. 1994. Characteristics of partnership success - partnership attributes, communication, Strategic Management Journal 15(2): 135-152.

http://dx.doi.org/10.1002/smj.4250150205 
Morgan, C. 2004. Structure, speed and salience: performance measurement in the supply chain, Business Process Management Journal 10(5): 522-536. http://dx.doi.org/10.1108/14637150410559207

Morgan, R.; Hunt, S. 1994. The long-term orientation-trust theory of relationship marketing, Journal of Marketing 58(3): 20-38. http://dx.doi.org/10.2307/1252308

Muralidharan, C.; Anantharaman, S.; Deshmukh, S. G. 2002. A multi-criteria group decision making model for supplier rating, The Journal of Supply Chain Management: a Global Review of Purchasing and Supply (November): 22-33.

Muralidharan, C.; Anantharaman, N.; Deshmukh, S. G. 2001. Vendor rating in purchasing scenario: a confidence interval approach, International Journal of Operations and Production Management 21(10): 1306-1325.

Neely, A.; Gregory, M.; Platts, K. 1995. Performance measurement systems design: a literature review and research agenda, International Journal of Operations and Production Management 15(4): 80-116. http://dx.doi.org/10.1108/01443579510083622

Nunnally, J. C. 1978. Psychometric Theory. $2^{\text {nd }}$ ed. New York: McGraw-Hill.

Perçin, S. 2006. An application of the integrated AHP-PGP model in supplier selection, Measuring Business Excellence 10(4): 34-49. http://dx.doi.org/10.1108/13683040610719263

Petersen, K. J.; Handfield, R. B.; Ragatz, G. L. 2005. Supplier integration into new product development: coordinating product, process and supply chain design, Journal of Operations Management 23: 371-388. http://dx.doi.org/10.1016/j.jom.2004.07.009

Roodhooft, F.; Konings, J. 1996. Vendor selection and evaluation: an activity based costing approach, European Journal of Operational Research 96: 97-102.

http://dx.doi.org/10.1016/0377-2217(95)00383-5

Samuel, H. H.; Keskar, H. 2007. Comprehensive and configurable metrics for supplier selection, International Journal of Production Economics 105: 510-523.

http://dx.doi.org/10.1016/j.ijpe.2006.04.020

Shepherd, C.; Gunter, H. 2006. Measuring supply chain performance: current research and future directions, International Journal of Productivity and Performance Management 55(3/4): 242-258. http://dx.doi.org/10.1108/17410400610653219

Sink, D. S.; Tuttle, T. C. 1989. Planning and Measurement in your Organisation of the Future Norcross. GA: Industrial Engineering and Management Press.

Stainer, A. 1997. Logistics - a productivity and performance perspective, Supply Chain Management 2(2): 53-62. http://dx.doi.org/10.1108/13598549710166104

Talluri, S.; Sarkis, J. 2002. A model for performance monitoring of suppliers, International Journal of Production Research 40(16): 4257-4269. http://dx.doi.org/10.1080/00207540210152894

Tan, K. C.; Lyman, S. B.; Wisner, J. D. 2002. Supply chain management: a strategic perspective, International Journal of Operations and Production Management 22(6): 614-631.

http://dx.doi.org/10.1108/01443570210427659

Tangen, S. 2004. Performance measurement: from philosophy to practice, International Journal of Productivity and Performance Management 53(8): 726-737.

http://dx.doi.org/10.1108/17410400410569134

Weber, C. A. 1996. A data envelopment analysis approach to measuring vendor performance, Supply Chain Management 1(1): 28-39. http://dx.doi.org/10.1108/13598549610155242 


\section{ANNEXURE}

\section{QUESTIONNARIE FOR SUPPLIER PERFORMANCE MEASUREMENT}

This survey is conducted for the academics purpose only.

Please answer the question based on the prevailing practices of your organization

Rate the following questions with a scale of 1 to 5. Put a circle mark against the appropriate box. Logic behind the numberings are

$5=$ Strongly agree to the statement

$4=$ Agree to the statement

$3=$ Neutral to the statement

$2=$ Disagree to the statement

$1=$ Strongly disagree to the statement

\begin{tabular}{|c|c|c|c|c|c|c|}
\hline Q1 & $\begin{array}{l}\text { Engineering knowledge like drawing, material type, process } \\
\text { knowledge and product knowledge are considered to be key } \\
\text { performance indicators in manufacturing set-ups. }\end{array}$ & 5 & 4 & 3 & 2 & 1 \\
\hline Q2 & $\begin{array}{l}\text { Improved product and service quality is always expected from } \\
\text { suppliers. }\end{array}$ & 5 & 4 & 3 & 2 & 1 \\
\hline Q3 & $\begin{array}{l}\text { Logistic ability of the supplier also considered during } \\
\text { performance measurement. }\end{array}$ & 5 & 4 & 3 & 2 & 1 \\
\hline Q4 & $\begin{array}{l}\text { Manufacturing Organisations expect to get maximum cost } \\
\text { benefits from outsourcing. }\end{array}$ & 5 & 4 & 3 & 2 & 1 \\
\hline Q5 & $\begin{array}{l}\text { Most of the manufacturing organisations give grate emphasis } \\
\text { on delivery reliability in comparison to cost. }\end{array}$ & 5 & 4 & 3 & 2 & 1 \\
\hline Q6 & $\begin{array}{l}\text { Buyers prefer suppliers having high effectiveness in aftersales } \\
\text { service. }\end{array}$ & 5 & 4 & 3 & 2 & 1 \\
\hline Q7 & $\begin{array}{l}\text { Way of submitting quotations, bills, challans, inspection reports } \\
\text { affects the performance index of the supplier }\end{array}$ & 5 & 4 & 3 & 2 & 1 \\
\hline Q8 & $\begin{array}{l}\text { Delivery flexibility adds additional weightage of being retained } \\
\text { as a supplier with comparison to other }\end{array}$ & 5 & 4 & 3 & 2 & 1 \\
\hline Q9 & $\begin{array}{l}\text { Responsiveness of the supplier at all levels of business process } \\
\text { has been one of the prime criteria of supplier performance } \\
\text { measurement. }\end{array}$ & 5 & 4 & 3 & 2 & 1 \\
\hline Q10 & $\begin{array}{l}\text { Ethical business practices are preferred in today's business } \\
\text { context from performance measurement system perspective }\end{array}$ & 5 & 4 & 3 & 2 & 1 \\
\hline Q11 & $\begin{array}{l}\text { Fair labour practice, Environmental and safety factors are } \\
\text { mandatory in supplier performance measurement for all sectors } \\
\text { of business }\end{array}$ & 5 & 4 & 3 & 2 & 1 \\
\hline Q12 & $\begin{array}{l}\text { Trust and commitments are also considered equally like cost, } \\
\text { quality and delivery in the performance index }\end{array}$ & 5 & 4 & 3 & 2 & 1 \\
\hline Q13 & $\begin{array}{l}\text { Supplier performance analysis is essential for supplier } \\
\text { retainership. }\end{array}$ & 5 & 4 & 3 & 2 & 1 \\
\hline
\end{tabular}


Manoj Kumar MOHANTY. Dr, 17 years of working experience in the field of supply chain, Operations management and Projects management in Larsen \& Toubro Limited, One of the most reputed Indian multinational company. Presently he is working as a project manager for department of crushing systems. He is having bachelor's degree in Industrial Engineering from Indian Institution of Industrial Engineering, bachelor's degree in computer applications from Sambalpur University, MBA in Operations Management from IGNOU, MSc in Engineering Business Management from Warwick University, $\mathrm{UK}$ and $\mathrm{PhD}$ in supplier relationship management from Sambalpur University. He is a strong believer of achieving operational efficiency and effectiveness through supplier relationship management. Currently he is working on supplier development and supplier satisfaction areas of supply chain management to provide long lasting partnership in manufacturing segment.

Padmabati GAHAN. Prof. (Dr), 27 years of post-graduate teaching experience in Utkal University and Sambalpur university of India and carries a very bright academic carrier. Currently she is working as professor of Business Administration Department, Sambalpur University. She is having 30 International and National publications so far. Her expertise areas are international finance, portfolio management, financial derivatives and valuation and volatility estimation. She has guided around 12 students for $\mathrm{PhD}$ degree. She has held the position of dean academics, comptroller of finance, and editor in chief for Journal of Management for the universities she has served. 